\title{
TRACE ELEMENT PROBLEMS IN THE WAIRARAPA
}

\author{
A. R. McIvor \\ Lincoln College, Canterbury
}

The PuRPose of this paper is to outline briefly the problems involving trace elements and to locate broadly the areas concerned within the district. Several major elements will also be discussed.

The problems appear to have two major effects and will be discussed in two sections: (1) Pasture development and production, and (2) Animal health.

The Wairarapa district contains approximately $1 \frac{1}{2}$ million acres of which $85 \%$ is hill country. Much of this area is steep and cannot be cultivated. Thus, by necessity, development of much of this district will be by aerial oversowing of clovers, topdressing and the positive use of stock. Measurement of success will be by eye appraisal of pastures, combined with the more factual information yielded by actual area stock carrying capacities and stock performance levels. The soils throughout the district are sedimentary and have been broadly classified as follows :

$$
\begin{array}{llllll}
\text { Plains soils } \quad \ldots . . & \ldots & \ldots & \ldots & \ldots & 211,763 \text { acres } \\
\text { Mudstones, limestones } & \text { siltstones } & \ldots & \ldots & 609,996 \text { acres } \\
\text { Argillite sandstone } & \ldots & \ldots & \ldots & \ldots & 288,460 \text { acres } \\
\text { Greywacke (steep) } & \ldots & \ldots . . & \ldots & \ldots & 311,910 \text { acres } \\
& & & & & 1,422,129 \text { acres }
\end{array}
$$

\section{PASTURE DEVELOPMENT AND PRODUCTION}

The problem area where difficulties are being experienced in achieving improved pasture production is on the acid soils in the merging area of the silts and sands. These soils are found in both the 35 to 40 in. rainfall belt and in the higher rainfall areas of 60 to 70 in. They are steep to moderately steep and subject to slipping, except the sandy loam (31e) which is flat. The New Zealand Soil Bureau list these as $28 \mathrm{cH}, 29 \mathrm{H}$ and $\mathrm{fH}$, $31 \mathrm{dH}$ and e, 32cH, 119 and 120. 


\section{Molybdenum Response}

Trace deficiencies of molybdenum appear to be present in many soils in the Wairarapa. Typical responses to molybdenum are seen as improved establishment of white clover with increased stock capacities. Molybdenum appears to be a necessary ingredient for pasture improvement on all the above listed soils, excluding Ngaumu fine, sandy loam, $32 \mathrm{cH}$. The requirement for molybdenum is usually satisfied by an initial application of 3 to $4 \mathrm{oz}$ with no further responses to molybdenum during the next four years. Herbage analysis generally indicates levels of $<1 \mathrm{ppm}$ before molybdenum is applied with increased levels of 1.5 to $2 \mathrm{ppm}$ at approximately 6 to 18 months following applications of 3 to $4 \mathrm{oz}$ of molybdenum.

\section{MOLyBdenum ANd Lime}

Quite spectacular responses have been gained by combining $10 \mathrm{cwt}$ of lime with $4 \mathrm{cwt}$ of phosphate plus 3 to $4 \mathrm{oz}$ of molybdenum (see Table 1). This applies particularly on Purimu silt loam $(31 \mathrm{dH})$ and also on the undeveloped areas of the loessal Kokatau silt loam (13d). It applies to a lesser extent on Kumeroa sandy loam $(29 \mathrm{fH})$, Marokopa clay loam $(28 \mathrm{cH})$, Te Wharau sandy loam (31e), Whareama silt loam (119) and Mataikona silt loam (120). Mowing plots on Marokopa clay loam, Kumeroa sandy loam and Purimu silt loam showed increases of 22 to $97 \%$ with the addition of lime to superphosphate and molybdenum (McIvor, 1966).

It has been noted that the best response to lime is obtained on native swards with a lesser change on sown pastures.

TABLE 1: SOIL TESTS OF PLOTS 9 TO 1.2 MONTHS AFTER APPLICATION

\begin{tabular}{|c|c|c|c|c|c|c|c|c|c|c|c|c|}
\hline \multirow[b]{2}{*}{ Control } & \multicolumn{2}{|c|}{$\begin{array}{c}13 d \\
p H \mathrm{Ca}\end{array}$} & $P$ & \multicolumn{2}{|c|}{$\begin{array}{c}27 \mathrm{cH} \\
p H \mathrm{Ca}\end{array}$} & \multirow{2}{*}{$\frac{\mathbf{P}}{4}$} & \multicolumn{3}{|c|}{$\begin{array}{c}28 c H \\
p H \mathrm{Ca}\end{array}$} & \multicolumn{3}{|c|}{$\begin{array}{r}31 d H \\
p H \mathrm{Ca}\end{array}$} \\
\hline & 5.0 & 4 & 2 & 5.3 & 4 & & & & $\mathbf{P}$ & 5.2 & 6 & 1 \\
\hline $4 \mathrm{cwt}$ Mo-Super. & 4.9 & 4 & 4 & 5.5 & 5 & 5 & 5.2 & 5 & 4 & 5.0 & 7 & 4 \\
\hline $8 \mathrm{cwt}$ Mo-Super. & 5.0 & 4 & 5 & 5.5 & 5 & 4 & 5.2 & 5 & 5 & 5.0 & 6 & 5 \\
\hline $\begin{array}{l}8 \text { cwt Mo-Super. }+ \\
1 \text { ton Lime }\end{array}$ & 5.4 & 5 & 10 & 5.9 & 8 & 8 & 5.5 & 6 & 8 & 5.3 & 6 & 5 \\
\hline
\end{tabular}

By courtesy of Wairarapa Farm Improvement Club, Annual Reporț, 1965. 
The questions that arise are:

(1) Has the lime an effect on the humus layer beyond the beneficial effect of the slightly raised $\mathrm{pH}$ ?

(2) In relation to molybdenum, one must ask whether advisers have sufficient information to decide when this element should be applied to pastures. Both trials and paddock capacities suggest that reduced capacities of three and a half ewes per acre can result from the use of phosphate alone where the soil requirement is for molybdenum and lime. Apart from soil maps, $\mathrm{pH}$ levels and data from trial work, advisers have no factual information regarding the molybdenum status of any specific area to be topdressed. In addition to the present soil testing facilities, would it not be possible to provide advisers with a herbage analysis service for molybdenum?

\section{SLOW RESPONSE OR Temporary EFfect}

On the Kumeroa sandy loam, Purimu silt loam and Mataikona silt loam, slow improvement in stock carrying capacity-or a slump of capacity following development have been experienced where these soils move into the higher rainfall areas of Te Wharau and to a limited extent in the foothills east of Carterton. The reasons for this-difficulty have not yet been established.

\section{higher Phosphate Maintenance Requirements}

This feature appears to be associated with the soft sands of the Ngaumu 'fine sandy loam, 32cH. 'Excluding the high rainfall areas of Te Wharau and the foothill areas, the annual maintenance level for hill soils, up to five ewes per acre, seems to be $1 \frac{1 / 2}{2}$ to $2 \mathrm{cwt}$ of superphosphate per acre. On Ngaumu fine sandy loam, the maintenance level appears to be at least $50 \%$ higher. This soil seems to have low retentive qualities with quick responses, but equally quick slumping if phosphate is omitted for twelve months.

The question is whether another more readily leached element such as sulphur is required as well as phosphorus.

\section{ANIMAL HEALTH}

\section{Slow Growth in Young animals and Lower Productivity}

This area extends over the higher rainfall areas of Mauriceville, Mount Bruce; Matahiwi and Kaituna. It is not suggested that this 
is the only area concerned, but this represents the extent to which I am able to define the area. Performance varies and no doubt there will be people who will dispute my contention that there is a problem.

The fact is, per-animal performance is at acceptable standards of 95 to $100 \%$ lambing from Romney ewes, with annual production of wool of 11 to $12 \mathrm{lb}$ per ewe equivalent in sheep. Comparison with other North Island high rainfall areas with lower performance may discount my suggestion. However, if one compares these perfcrmances with those on the drier hills within the district, one finds examples under comparable good management standards, where lambing percentage is moving to 107 to $110 \%$ from Romneys with 13 to $14 \mathrm{lb}$ of wool per ewe equivalent. (The ewe equivalent in sheep/wool expression is factual and therefore a more accurate means of comparison than the ewe, hogget, lamb/wool expression which is based largely on assumption.) In comparing growth rates of weaned lambs, it is found that coastal lambs tend to be $10 \mathrm{lb}$ heavier in March-April than those in the area under discussion. This applies to both Romney and RomneyBorder cross lambs.

This problem also extends into the Wangaehu and is experienced there only in lower lamb growth rates. These observations arc based on three years' records of ewe lamb weights.

\section{Copper, Selentum}

Copper, selenium and cobalt have all been investigated throughout the district with mostly indifferent results. Practically all the work in which I have been associated in the Wairarapa has indicated that no significant copper deficiency exists. However, more recently blood analysis from cattle slaughtered at the works has shown abnormally low copper analysis. Some properties which have topdressed with copper have shown responses in cattle thrift, though these responses cannot be stated as entirely due to the application of copper.

It appears that improved growth rates in cattle and lambs, plus a possible increase in lambing percentage, could be achieved from a thorough investigation of the relationship of selenium and copper on selected farms. Soil types concerned are Atua Hill soils $29 \mathrm{H}, 114$, Purimu silt loam $31 \mathrm{dH}$, Ngaumu fine sandy loam $32 \mathrm{cH}$ and Marakopa clay $28 \mathrm{cH}$.

No conclusive results have been. seen from cobalt, 


\section{Grass Staggers of Breeding Cows}

This problem has been receiving increasing attention, with very valuable findings, particularly in the work of Metson, Saunders, Collie and Graham. It appears to be a danger on limestone soils, good clays, such as the Mangatea and Taihape $(25 \mathrm{H}$, 114a), and on the brown loams through Mount Bruce, Matahiwi, Mauriceville and Kaituna.

This problem develops as soil fertility rises with pasture improvement and management will increasingly need to plan to bridge this late August to October danger period with magnesium supplements.

Autumn grass Staggers in EWes and Lambs

This problem occurs every two or three years and coincides with the very dry years when prolonged periods of hot weather have browned off pastures. The condition develops from late February to April. Observations suggest the following facts:

(1) It occurs only during prolonged periods of dry weather' with high temperatures.

(2) It occurs on dried pastures consisting of either sown ryegrasses or undeveloped browntop native pastures. Newly sown pastures seem less toxic.

(3) It affects young sheep more severely and earlier than mature ewes. Horses and calves are also affected.

(4) It occurs at the same period as facial eczema.

(5) Animals fed entirely on hay or straws are not affected,

(6) Though animals begin to recover as soon as pastures freshen following rain, a lapse of three weeks often occurs before all animals have recovered.

The economic significance lies first in the reduced wool clip of $1 \frac{1}{2}$ to $2 \mathrm{lb}$ from hoggets, a smaller reduction in ewe fleeces and lower lambing percentages.

It is difficult to disentangle the clear cause and effect because of the association with droughty conditions with water and feed stress. However, we must ask ourselves whether we are allotting too much emphasis to drought and ignoring the effect of this disease.

$$
\text { REFERENCE }
$$

McIvor, A, R., 1966: Sheepfmg A:215-23. 